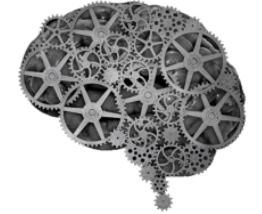

COMPANY GROUP "INTELLEKT"

Рогуленко Т.М., Торпашов В.С. Государственный университет управления Москва, Россия

doi: 10.18411/1j2016-5-4-07

\title{
Краткий очерк становления современной отечественной авиаотрасли и роль государства в ее развитии
}

Авиастроение - высокотехнологичный сектор промышленности, определяющий уровень развития национальной экономики, степень её прогрессивности, конкурентоспособности и технологического потенциала.

Авиационная промышленность как специфический сектор экономики обладает, вне зависимости от национальной или региональной принадлежности, некоторыми общими особенностями, присущими как самой отрасли, так и ее продукции (рис.1).

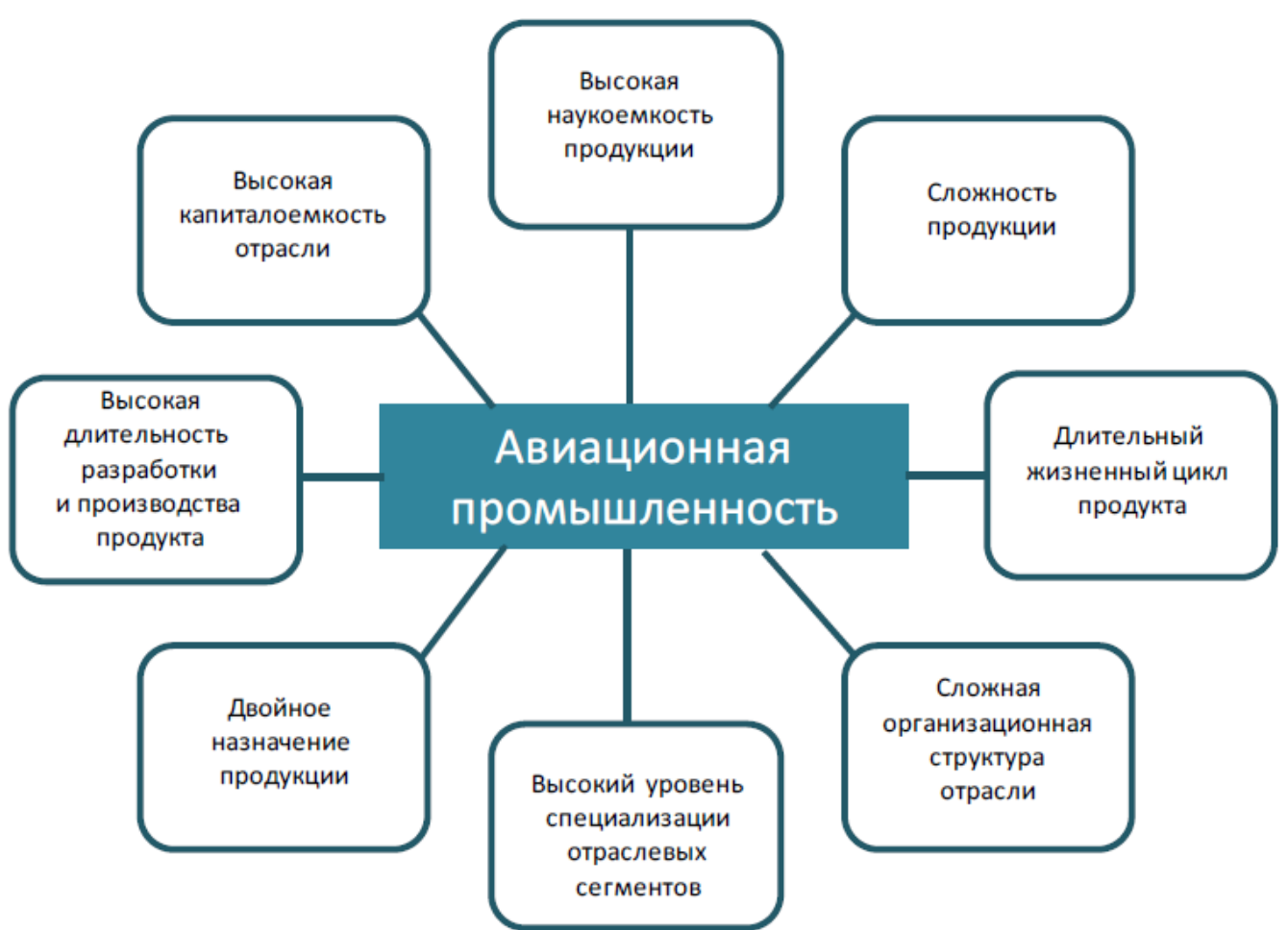

Рис.1. Специфические особенности авиационной промышленности и выпускаемой ею продукции 
Авиастроению присущ высокий уровень специализации отраслевых сегментов. В зависимости от вида летательного аппарата, на создании которого специализируются предприятия, отрасль делится на технологические сегменты самолетостроения и вертолетостроения (специализация по типу летательного аппарата). В зависимости от отношения к стадиям жизненного цикла изделия, предприятия и организации авиастроительного комплекса образуют сегменты отрасли - научно-исследовательский, проектный $\quad$ и производственный (специализация по стадиям жизненного цикла). В зависимости от конструктивно-технологической стадии создания летательного аппарата (летательный аппарат в целом либо его составляющая), на реализации которой специализируется предприятие, отрасль делится на следующие сегменты: создание летательного аппарата в целом, создание двигателей, авионики, оборудования и систем (специализация по элементам конструкции).

Совокупность отдельных сегментов авиастроения, существующих в стране, формирует технологический состав национальной авиационной промышленности. Страны и регионы (как в случае с Европейским Союзом) ведущие мировые производители авиационной техники - имеют на своей территории несколько промышленных сегментов - авиастроение, авиационное двигателестроение, авиационное приборостроение, агрегатостроение, авиационное оборудование и авиационное вооружение.

И вся это совокупность специализаций и сегментов авиастроения вместе образуют сложную организационную структуру отрасли.

Какая же организационная структура авиационной промышленности сформировалась к настоящему времени в нашей стране? Чтоб ответить на этот вопрос, рассмотрим этапы ее формирования, начиная от последних лет существования СССР до наших дней. Здесь не будем подробно рассматривать все изменения, которые возникали в отечественной авиационной промышленности в эти непростые для страны годы перехода от 
административно-командной экономики к рыночной, а кратко отметим основные моменты, проблемы и результаты работ.

В СССР авиационная отрасль традиционно рассматривалась как фактор национальной безопасности, важный источник национального дохода, сфера высококвалифицированной занятости, средство поддержания имиджа развитой в научном и технологическом отношении страны.

Управление авиапредприятиями в отрасли осуществлялось созданным еще в 1939 году Министерством авиационной промышленности (до 1946 г. Наркомат авиационной промышленности). Минавиапром СССР, согласно Положению руководил промышленностью (отраслью) по производству самолётов, вертолетов и других летательных аппаратов, двигателей, запасных частей, приборов, агрегатов и специальной техники по профилю Министерства.

Аппарат Министерства авиационной промышленности и подведомственные ему предприятия, организации и учреждения составляли единую систему Министерства авиационной промышленности СССР. Структура Министерства авиационной промышленности 1980-х годов представлена на рис.2. Помимо представленных на рис.2 в части создания авиационной техники главных управлений, в структуру Министерства авиационной промышленности входили также Руководство Министерства (Министр и заместители Министра); Общественные организации (Партком и Профком); Главное плановопроизводственное управление; ГУ материально-технического снабжения; ГУ комплектации; ГУ сбыта и гражданской продукции; Управление главного механика и главного энергетика; Управление организации труда, зарплаты и рабочих кадров; Финансовое управление; Управление бухгалтерского учёта и отчётности; Управление по контролю качества продукции; Юридическое управление с арбитражем; Хозяйственное управление

В последние годы существования СССР авиационная промышленность сохраняла ранее созданную способность разрабатывать и серийно выпускать все основные виды гражданской и военной авиатехники, включая практически всю 
номенклатуру материалов и комплектующих для самолетов и вертолетов. Численность занятых в авиапроме превышала 2 млн человек. В ведении Министерства авиационной промышленности (МАП) находилось около 250 предприятий, непосредственно занимавшихся разработкой и производством авиационной техники. Длинные технологические цепочки ее создания выходили за формальные границы отрасли и вовлекали в серийноепроизводство самолетов и вертолетов многочисленные предприятия смежных отраслей.

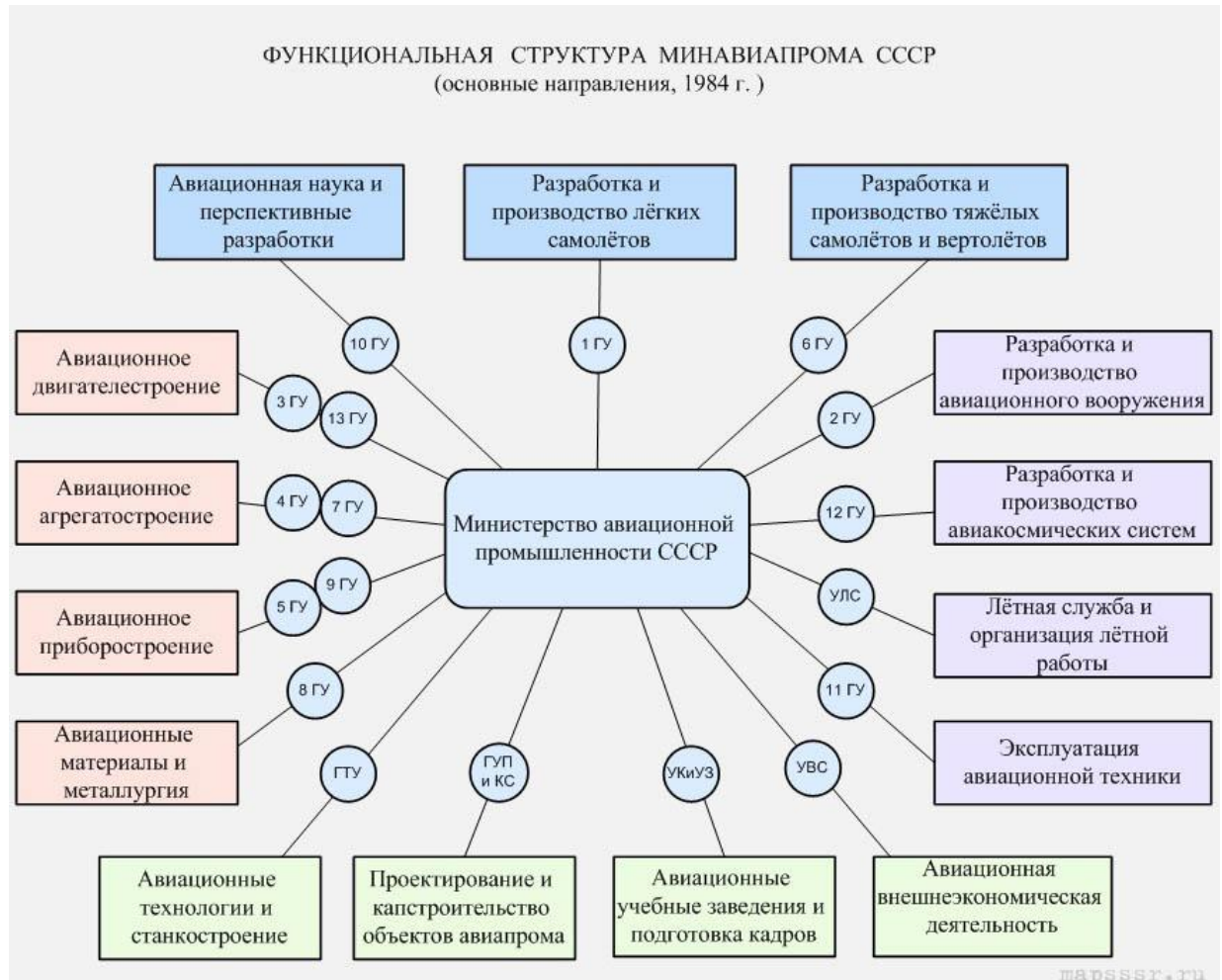

Рис.2. Структура Министерства авиационной промышленности СССР

(на рис. принятые сокращения: ГУ - главное управление; УЛС - Управление лётной службы;

УВС - Управление внешних сношений; УКиУЗ- Управление кадров и учебных заведений;

ГУП и КС -главное управление проектирования и капитального строительства;

ГТУ - Главное техническое управление)

Отрасль была сориентирована преимущественно на разработку и производство военной авиатехники. В конце 1970-х - начале 1980-х годов в СССР ежегодно производились сотни самолетов и вертолетов военного назначения для оснащения Вооруженных сил и поставки на экспорт. Но и в гражданском сегменте в советские годы было организовано серийное производство: в год выпускалось до 150 самолетов и около 300 вертолетов.Выпуск гражданской авиатехники обеспечивал не только внутренние 
потребности, но и экспортные поставки - в основном в социалистические страны.

Таким образом, управление отраслью в эпоху тех социалистических лет осуществлялось полностью государственными структурами. Они указывали какую и сколько производить авиационной техники для нужд народного хозяйства, главные управления министерства вели координацию и учет ее изготовления согласно принятым планам.

Конечно, неоспоримо, что в то время в авиационной отрасли было сделано очень много чего, но всю эту тогдашнюю систему взаимодействия невозможно было переместить в рыночные условия, она, как говорится, является достижением "социализма".

Министерство авиационной промышленности СССР (в связи с наметившими в начале 90-х годов политическими и экономическими переменами) прекратило свою деятельность 1 декабря 1991 года, и было ликвидировано к 26 декабря 1991 года.

Здесь хочется отметить, что после распада СССР, на территории России на момент обретения государственной независимости располагалось 214 предприятий отрасли, включая 28 НИИ, 72 ОКБ и 114 серийных заводов, то есть практически все организации и учреждения отраслевой науки, основная доля конструкторского и производственного потенциала советского авиастроительного комплекса. Таким образом, Россия в начале 1990-х годов стала обладательницей одного из крупнейших в мире авиастроительных промышленных комплексов. На еe территории оказалось около 30 только сборочных заводов, обеспечивавших финальный выпуск самолетов, вертолетов и двигателей. Поэтому неудивительно, что сохранение и развитие национальной авиапромышленности сразу же было объявлено в независимой России государственным приоритетом. Считалось, что эта отрасль должна стать локомотивом высокотехнологичного развития экономики. Но как управлять всем этим наследием в новых быстроменяющихся условиях рыночной 
экономики в купе с большими экономическими и социальными проблемами тех лет.

Мы не будем рассматривать подробно все проблемы и перемены, происходящие в авиационной отрасли в то время, а отметим только что результаты российской авиастроительной отрасли к концу 1990-х годов трудно признать успешными. Конверсия, приватизация, либерализация экономической деятельности, отсутствие заказов, отъезд за границу многих талантливых сотрудников, износ основных фондов, структурные преобразования - все это привело к тому, что авиационная промышленность, особенно в гражданском сегменте, находилась в глубоком системном кризисе.

По формальным признакам авиапромышленность после начала рыночных реформ была объектом повышенного внимания со стороны органов государственного управления. Вот только проводимая экономическая политика не отличалась ни эффективностью, ни реалистичностью. Сочетание слабого государственного управления и влиятельности отраслевого лобби сводило ее преимущественно к принятию многочисленных постановлений, планов и программ, предусматривавших продолжение советской практики государственного субсидирования. Соответственно главной целью разобщенных экономических субъектов отрасли было стремление получить доступ к дотационному каналу государственного финансирования, а не завоевать конкурентные позиции на авиационном рынке. Скудность этого источника и отсутствие эффективной политики управления привели к существенному ослаблению отрасли даже по сравнению с началом 1990-х годов.

Однако возможности возрождения отрасли не были утрачены безвозвратно, что и обеспечило в 2000-е годы некоторый подъем производства и основу для дальнейшего реформирования.

В 2000-е годы объем производства продукции авиационной промышленности стал год от года расти, чему способствовали общий рост экономики и связанная с ним возможность увеличения бюджетного 
финансирования отрасли. Дезинтеграция авиастроительных предприятий была остановлена. Давно ожидаемое объединение предприятий отрасли привело к возрастанию роли государства в качестве собственника авиастроительных активов, что фактически означало частичнуюренационализацию отрасли.

В 2004 году в рамках дискуссии об использовании Стабилизационного фонда для увеличения бюджетного финансирования реального сектора экономики правительство дало старт кампании разработки отраслевых стратегий. На увеличение бюджетного финансирования могли претендовать отрасли, которые представят внятные стратегии развития в рамках популярной на тот момент парадигмы «частно-государственного партнерства». В кампанию включилась и авиационная промышленность. К концу года была разработана «Стратегия развития авиационной промышленности до 2015 года».

В начале 2000-х годов обозначилось два подхода к структурным реформам в авиастроительном комплексе. Носителем одного из них были отраслевые органы государственного управления, а другого - частные структуры, сформировавшиеся в отрасли в результате институциональных и структурных реформ 1990-х годов и набравшие к началу 2000-х политический вес, накопившие опыт структурных преобразований и располагавшие финансовыми возможностями.

Опыт 1990-х годов показывал, что различные категории собственников с несовпадающими позициями и интересами по вопросам объединения, различные организационно-правовые формы намеченных к объединению предприятий, слабость и изменчивость системы государственного управления и отсутствие очевидных мотиваций руководителей предприятий сделают процесс реализации целей федерально-целевой программы бесконечным. Это мотивировало частных собственников авиастроительных активов на альтернативную инициативу создания объединенной авиастроительной компании, контролируемой частными акционерами. 
Правительство поддержало эту инициативу и решило включить в создаваемую Объединенную авиастроительную корпорацию (ОАК) государственные активы. Это решение было подтверждено в «Стратегии развития авиационной промышленности на период до 2015 года», где в качестве одной из важнейших задач было определено формирование новой организационной структуры отрасли, предполагающей ликвидацию разобщенности авиастроительных комплексов и объединение авиастроительных активов и бизнесов в ограниченном числе крупных компаний (самолетостроительной, вертолетостроительной, моторостроительной и др.), способных проводить политику создания и продвижения на рынки конкурентоспособной продукции.

Аналогичные процессы интеграции прошли и в других подотраслях. Так, в декабре 2006 года было образовано ОАО «Вертолеты России». В апреле 2008 года была образована Объединенная двигателестроительная корпорация. На базе предприятий авиапрома, специализировавшихся в области авиационного вооружения, создана корпорация «Тактическое ракетное вооружение». А госкорпорация «Российские технологии» на базе предприятий авиаприборостроения и авиаагрегатостроения формирует приборостроительные холдинги.

Таким образом, за первое десятилетие 2000-х годов облик авиационной промышленности существенно изменился. Разрозненные предприятия были собраны в крупные отраслевые корпорации, абсолютно преобладающей стала государственная собственность. Бюджетное финансирование проектов и программ авиастроения многократно увеличилось. Динамика выпуска самолетов и особенно вертолетов стала положительной. Несмотря на то, что формируемые интегрированные структуры пока не стали полноценными корпорациями, а длительные циклы разработки и подготовки производства авиационной техники еще не завершились выводом на рынок продуктов нового поколения, деградация отрасли к тому времени была остановлена. 
Авторы статьи не зря кратко описали реструктуризацию отечественной авиационной отрасли, начиная с последних годов существования СССР до 2010 года, с целью показать, что роль государства в такой отрасли как авиационная промышленность весьма и весьма велика (хотя, что касается СССР, то роль государства было само собой очевидным в силу существования в то время социалистического строя).

И здесь следует отметить, что это не есть характерная особенность нашей страны. Да, традиционно принято считать, что государственную поддержку следует оказывать только тем отраслям, которые производят общественные блага, либо, отраслям, находящимся на стадии становления - т.н. infantindustries. Авиатехника и ее послепродажное обслуживание не являются общественными благами, обладают с точки зрения институциональной экономики всеми свойствами частных благ, могут и должны реализовываться на рынках. T.e. первое возможное объяснение необходимости господдержки отпадает. К зарождающимся отраслям можно было отнести авиастроение Западной Европы (концерн AirbusIndustry) в первые годы его работы, причем, именно этим мотивировалась массированная финансовая поддержка создания первых типов самолетов Airbus за счет налогоплательщиков стран Европейского союза (EC). Однако к настоящему времени AirbusIndustry, представленный на мировом рынке уже более 30 лет и контролирующий около половины мирового рынка магистральных коммерческих самолетов, сложно отнести к категории infant. Тем более сложно отнести к этой категории авиастроение США и компанию Boeing. Однако оба ведущих игрока мирового рынка гражданской авиатехники регулярно получают в различных формах помощь со стороны своих правительств, что порой приводит к различным взаимным претензиям и разбирательствам в судах. Является ли это лишь примером недобросовестной конкуренции, результатом лоббирования узкоотраслевых интересов и поиска ренты, или обусловлено объективными экономическими особенностями отрасли? 
Но вернемся к рассматриванию уже сформировавшейсясовременной структуры авиационной промышленности и кратко опишем имеющиеся проблемы.

Итак, как отмечалось выше, одной из ключевых системных инициатив в отрасли стало объединение обособленных авиастроительных предприятий в крупные интегрированные структуры. Предпосылками создания интегрированных структур в авиастроении явилась необходимость концентрации ресурсов на реализации ключевых проектах, обеспечения специализации производств, сокращения дублирующих производственных мощностей, высвобождения капитала и ресурсов, роста капитализации компаний и мобилизации капитала для инвестиций в новые проекты. Интеграция авиастроительных предприятий в холдинги позволила существенно повысить экономическую эффективность их деятельности: в последние годы отмечается неуклонный рост консолидированной выручки авиастроительных холдингов. Кроме того, в соответствии с корпоративными стратегиями осуществляется внедрение новой индустриальной модели, предполагающей техническое перевооружение предприятий отрасли. Основными целями стратегий являются снижение себестоимости продукции и повышение конкурентоспособности отечественной авиационной техники на внутреннем и внешнем рынках. Важным результатом их реализации станет и увеличение налоговых поступлений в бюджеты различных уровней.

Таким образом, современную структуру российского авиастроительного комплекса определяют интегрированные структуры, объединяющие предприятия авиастроения по продуктовому признаку. Системообразующие отраслевые холдинги созданы в таких секторах (подотраслях) авиастроения как самолетостроение, вертолетостроение, авиационное двигателестроение, авиационное приборостроение, авиационное оборудование и авиационное вооружение. 
В составе авиационной промышленности созданы следующие основные интегрированные структуры: ПАО «Объединенная авиастроительная корпорация» (ПАО «ОАК»), ПАО «ОПК «Оборонпром», включающая ПАО «Вертолеты России» и ПАО «Объединенная двигателестроительная корпорация» (само же ПАО «ОПК «Оборонпром» входит в госкорпорацию «Ростех»), АО «Концерн Радиоэлектронные технологии» (КРЭТ) (также входит в состав госкорпорации «Ростех»).

По организации - это вертикально интегрированные структуры, обеспечивающие полный цикл создания, производства и поддержки эксплуатации конечных изделий. В этих структурах государственная форма собственности является доминирующей.

Целевой сценарий долгосрочного развития авиапромышленного комплекса России также формально определен. Он содержится в ряде официально принятых документов, определяющих развитие отрасли и еe подотраслей. К основному перечню таких документов относятся «Стратегия развития авиационной промышленности», «Стратегия развития газотурбинного двигателестроения», «Государственная программа вооружений», ФЦП «Развитие ОПК», ФЦП «Развитие гражданской авиационной техники России». К этой же группе документов федерального уровня относятся отдельные решения Правительства Российской Федерации, межправительственные соглашения в сфере военно-технического сотрудничества и отдельных авиастроительных проектов. Сценарии долгосрочного развития отражены и в документах корпоративного уровня, таких как стратегии развития «Объединенной авиастроительной корпорации», «Объединенной двигателестроительной корпорации», «Вертолетов России» и других отраслевых интегрированных структур.

И вся это сложная структура авиационной промышленности, включающая в себя различные интегрированные корпорации, состоящие из предприятий и компаний различного рода деятельности (от предприятий поставщиков разного 
вида материалов, комплектующих, агрегатов, приборов, оборудования, систем до предприятий конечного выпуска авиационной техники - летательного аппарата), находится в непростых условиях современной рыночной экономики, в которой на вопросы: Что? Сколько? Как? Для кого производить? - она должна давать ответы, тем самым находясь в непрерывном совершенствовании и быть конкурентоспособной не только на внутреннем, но и на мировом рынке.

В современном, открытом и взаимосвязанном мире крайне необходимым становится изучение закономерностей функционирования и развития рыночной системы и организации финансово-хозяйственной деятельности предприятий.

Современная экономика требует от предприятий повышения эффективности производства, конкурентоспособности продукции и услуг, использования новейших достижений науки, техники и технологии, эффективных форм управления и хозяйствования, активизации предпринимательства и преодоления бесхозяйственности.

Одной из основных движущих сил в создании новой техники является потребность в ней. Определившись с потребностью в новой технике, начинается процесс еe создания (проектирование и конструирование), изготовление (производство) и дальнейшая ее эксплуатация (см.рис.3).

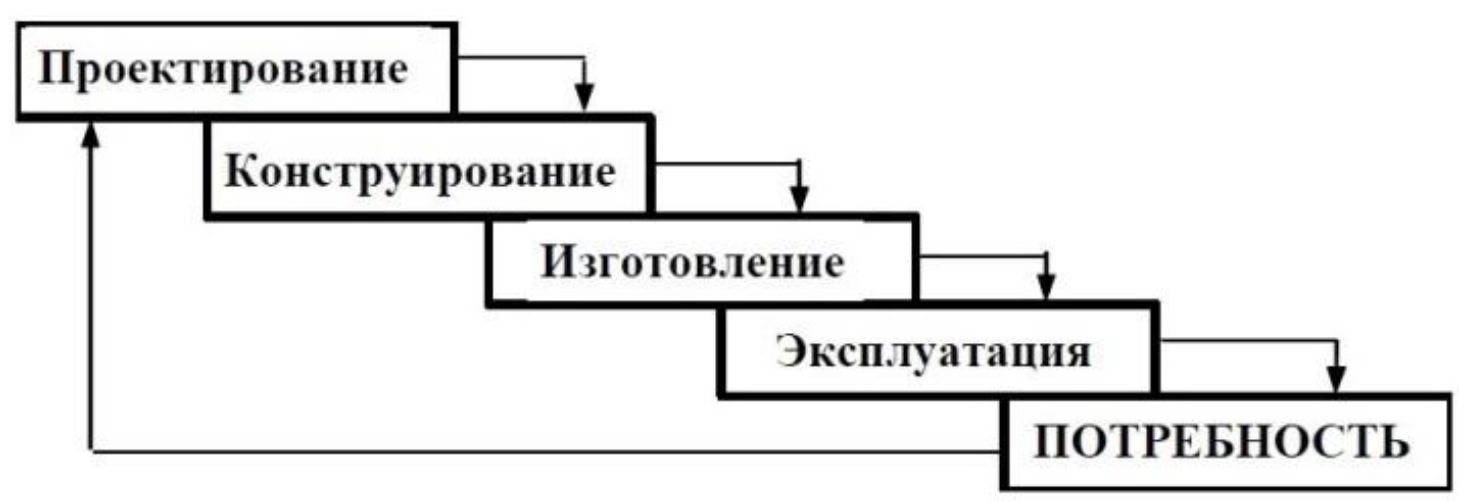

Рис.3. Прочесс создания изделия 


\section{Q EOEINE}

\section{ПРОГНОЗ РЫНКА ГРАЖДАНСКОЙ АВИАЦИИ 2014-2033}

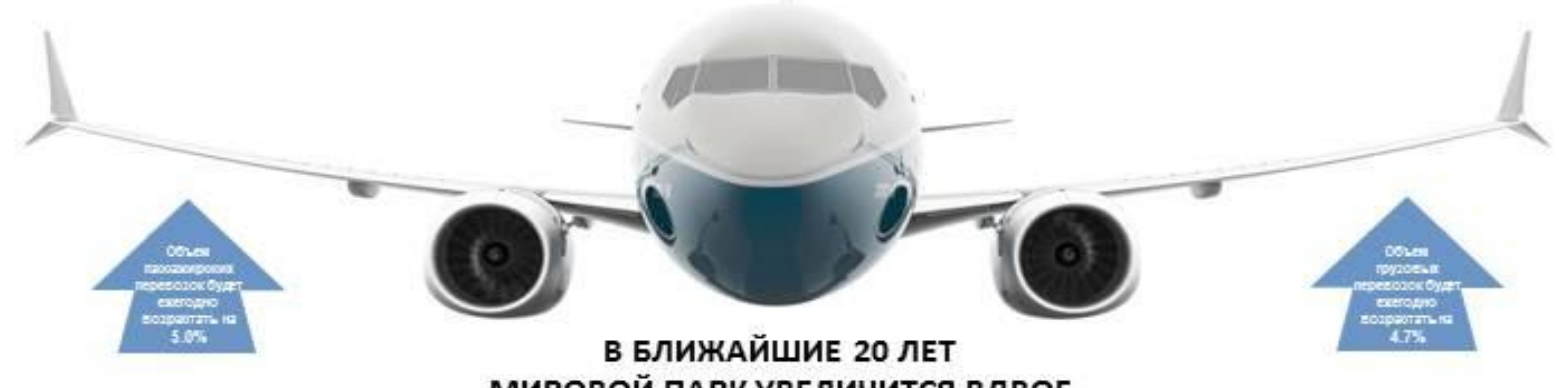

МИРОВОЙ ПАРК УВЕЛИЧИТСЯ ВДВОЕ

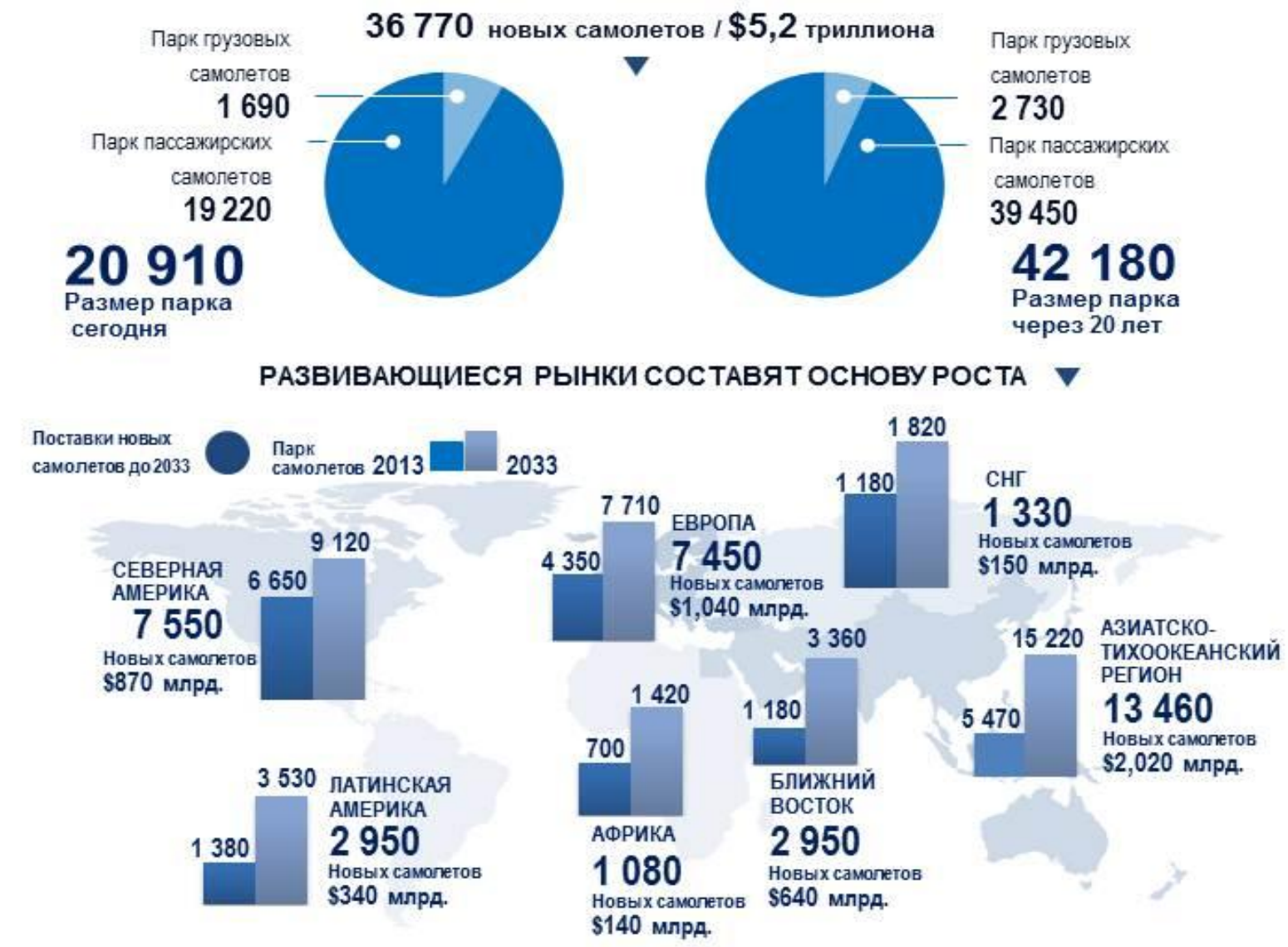

НОВЫЕ САМОЛЕТЫ, КОТОРЫЕ БУДУТПОСТАВЛЕНЫДО 2033 ГОДА $\nabla$

РЕГИОНАЛЬНЬЕ УЗКОФЮЗЕЛЯЖНЬЕ МАЛЫЕШИРОКОФЮЗЕЛЯЖНЫЕ СРЕДНИЕШИРОКОФЮЗЕЛЯЖНЫЕ БОЛЬШИЕ
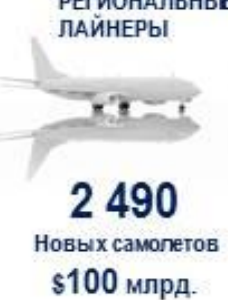
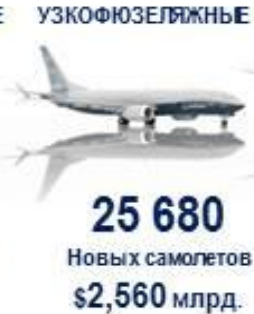
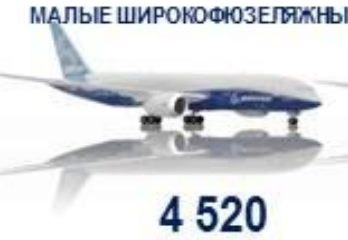

Новых самолетов $\$ 1,140$ млрд.

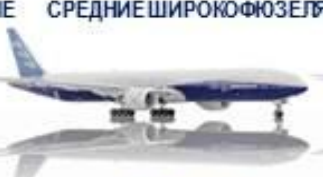

3460

Новых самолетов $\$ 1,160$ млрд.

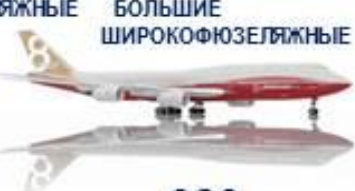

620

Новых самопетов $\$ 240$ млрд.

Рис.4. Прогноз мирового рынка гражданских самолетов на период 2014-2033 г2., разработанный компанией «Boeing»

Потребность в современной авиационной технике (другими словами, спрос) изучается различными аналитическими центрами, департаментами, 
самими авиационными корпорациями. На основании этих данных строятся прогнозы и создаются планы (программы) стратегического развития авиационной промышленности. К примеру, на рис.4 показан прогноз мирового рынка гражданской авиации, разработанный компанией «Boeing» (такие же прогнозы рынка есть и у «ОАК» и у «Airbus»). Как видим из рисунка, потребность в новых самолетах неуклонно будет возрастать и отечественной авиапромышленности есть хорошие шансы иметь свою долю мирового рынка. С этой целью разработана государственная программа «Развитие авиационной промышленности на 2013-2025 годы», одной из основных целей которойявляется создание высококонкурентной авиационной промышленности и закрепление ее позиции на мировом рынке в качестве третьего производителя по объемам выпуска авиационной техники. Для достижения этой цели по подпрограмме «Самолетостроение» необходимо решение ряда приоритетных задач, включая:

• завершение реструктуризации самолетостроительной отрасли;

- расширение присутствия организаций самолетостроения на рынке;

- развитие глобальной сервисной сети и системы послепродажного обслуживания;

- обеспечение потребностей Российской Федерации в гражданской авиатехнике в значительной степени за счет отечественной продукции.

Помимо привлечения для финансирования частных инвесторов немалые средства будут выделяться из федерального бюджета (в общем более 714 млрд рублей на всю госпрограмму в 2013-2025 годах (в ценах соответствующих лет), из них планируется выделить свыше 83 млрд рублей на реализацию подпрограммы «Самолетостроение» из федерального бюджета, см. рис.5). 


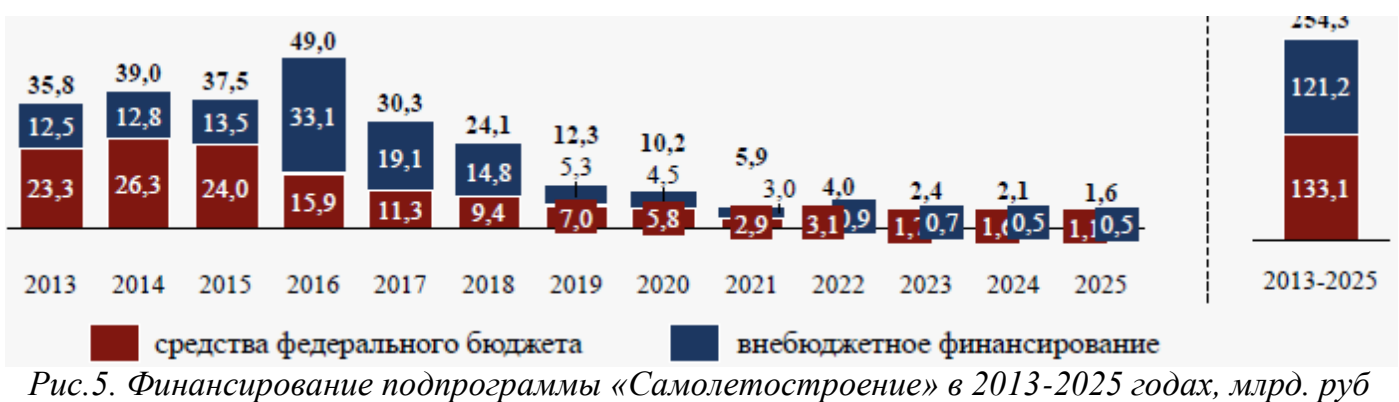

На вопросы «Что?» и «Сколько?» производить авиапромышленность уже имеет определенные ответы. Какие же продукты для реализации на рынке имеются у отечественной авиапромышленности (здесь мы уже перешли к рассмотрению гражданского самолетостроения, как подотрасли авиационной промышленности с наиболее проблемными вопросами еe реализации на мировом рынке). Это новый спроектированный, построенный и уже эксплуатируемый авиакомпаниями региональный самолет SukhoiSuperjet 100 (SSJ 100); находящийся на этапе постройки опытного образца узкофюзеляжный самолет MC-21, ориентированный на самый массовый сегмент мирового рынка авиалайнеров (см.рис.4); в сегменте широкофюзеляжных самолетов разработка современного российско-китайского авиалайнера. Также имеются хорошо зарекомендовавшие себя самолеты Ту-204/214, Ил-96, спроектированные на закате СССР, но, к сожалению, ввиду непростой ситуации в стране после распада СССР из-за плохо развитого маркетинга и послепродажного обслуживания не нашедшие объемные рынки сбыта.

Остаются вопросы «Как?» и «Для кого производить?», но эти вопросы требуют более глубокого рассмотрения всей широты деятельности авиационной промышленности, в которой тесно связаны принимаемые конструкторские, технологические и управленческие решения по созданию новой авиационной техники, и в данной статье не рассматриваются. Здесь же кратко хочется отметить еще ряд проблем отечественной авиапромышленности и подчеркнуть важность роли государства в ее развитии.

Да, безусловно, многие проблемы, которые мы сегодня отмечаем в российской авиационной промышленности, являются объективным следствием 
сложной экономической ситуации 1990-х годов. Однако гораздо больший ущерб конкурентоспособности отрасли нанесло и продолжает наносить пренебрежительное отношение к жизненно важным функциям, которые были сосредоточены за периметром Министерства авиационной промышленности. Наибольший подъем в отечественном авиастроении пришелся на период планового хозяйства, в силу чего многие функции, свойственные рыночным экономикам, в отрасли не развивались. Маркетинг и продажи были заменены государственным планированием. Общая координация в отрасли - построение кооперационных цепочек, взаимодействие конструкторских бюро и серийных заводов, взаимодействие фундаментальной и прикладной науки с отраслями промышленности - осуществлялась на уровне министерств и ведомств. Послепродажное обслуживание велось силами эксплуатантов (гражданских и военных) и отдельными авиаремонтными заводами, участие авиационной промышленности сводилось к авторскому надзору со стороны конструкторских бюро. В результате российский авиапром не смог вписаться в рыночную экономику со своим массовым, но морально устаревшим продуктом и, что не менее важно, с морально устаревшей философией разработчиков, не умевших прислушиваться к запросам потребителей.

Сегодня можно с уверенностью говорить о том, что за счет принятых мер авиационная промышленность вышла из «крутого пике». Однако для уверенного набора высоты не хватает последовательной и скоординированной работы заинтересованных сторон: правительства и предприятий. Авиастроительный мир радикально изменился за последние десятилетия. Спрос больше не является ограничением - олигополистическое предложение диктует правила авиакомпаниям-потребителям. Для России, которая практически не представлена на рынке гражданской авиации, это означает, что любой путь открыт с точки зрения востребованности конкурентоспособной продукции. С другой стороны, еще выше стали барьеры для выхода в отрасль. Теперь недостаточно произвести продукцию с характеристиками лучше, чем у 
конкурентов: необходимо быть финансово устойчивой компанией, иметь доказанные производственные мощности и безупречную репутацию надежного поставщика, корпоративную прозрачность, глобальную сеть послепродажного обслуживания и многое другое. Конкурируют не продукты, а компании - всей совокупностью своих ресурсов и компетенций, при мощнейшей поддержке собственных национальных правительств. Таким образом, требуются продуманные, последовательные и смелые политические решения (экономистылибералы называют их «нерыночными») по принудительному оснащению ведущих полугосударственных авиакомпаний-перевозчиков отечественными самолетами, невзирая на первых порах на их коммерческую неконкурентоспособность перед «боингами» и «эйрбасами». Не создав собственную технологическую базу, под которую на первых порах следует поддерживать искусственный спрос, невозможно будет достичь лучших мировых стандартов. Ведь отечественная авиация фактически уже прошла этот путь в 20-40 годах. Авиационные технологии, возникшие в результате сталинской индустриализации, в значительной степени были заимствованы у Запада, и первые советские самолеты, предназначавшиеся для оборонного использования, были отнюдь не самого лучшего качества. Но в течение последующих 20 лет, к началу 60-х годов, СССР превратился, по крайней мере, во вторую авиационную державу мира (после США) как по номенклатуре производившихся самолетов, так и уровню технологий.

Очевидно и то, что авиационная промышленность, создание которой в нашей стране началось уже больше века назад, играет системообразующую роль в экономике Российской Федерации. Благодаря тесной связи с другими (обеспечивающими) отраслями ее развитие как одной из наиболее наукоемких и инновационных отраслей экономики способно оказать значительное влияние на темпы перехода страны на инновационные рельсы развития. Стабильная работа отрасли создает предпосылки для сохранения и развития целого ряда высокотехнологичных предприятий, обеспечивает «интеллектуализацию» 
структуры ВВП, опережающее развитие экспорта продукции машиностроительного комплекса, а также импортозамещение в ключевых продуктовых сегментах.

Также авиационная промышленность является важнейшим элементом обеспечения интересов Российской Федерации в оборонной и военнополитической сферах в силу возрастания значения авиации в решении соответствующих задач. Авиационная промышленность является важным фактором поддержания суверенитета страны, наращивания боевого потенциала государственной авиации в соответствии с требованиями обеспечения обороноспособности страны, развития международного военно-технического сотрудничества.

Авиационная промышленность играет и особую социальную роль в экономике Российской Федерации: насчитывая более 200 предприятий, она обеспечивает в настоящее время более 400 тысяч высококвалифицированных рабочих мест на производстве, в научно-исследовательских институтах, конструкторских бюро, вузах и техникумах. При этом для нее неизменными остаются главные задачи - обеспечение безопасности страны и (наряду с другими видами транспорта) территориальной мобильности и межрегиональной интеграции. 


\section{Литература:}

1. Государственная программа Российской Федерации «Развитие авиационной промышленности на 2013-2025 годы». Режим доступа. URL:http://minpromtorg.gov.ru/common/upload/files/docs/Vizualizatsiya_GP_ RAP_140507.pdf

2. Стратегическая программа исследований и разработок «Технологическая платформа «Авиационная мобильность и авиационные технологии». Режим доступа. URL: https://www.hse.ru/org/hse/tp/airspace_mobil/docs

3. Указ Президента РФ №140 от 20 февраля 2006 г. «Об открытом акционерном обществе «Объединенная авиастроительная корпорация»

4. БогдановаЛ. С., Ляшко Е. Ф., Махитько В. П. Финансово-экономический анализ в авиастроении: Учебное пособие. - Ульяновск: УлГТУ, 2006.-96 с.

5. Колпаков С.К., Алексеев В.П., Селиванова Н.А., Сухарев А.А., Власенко А.О., Москвин А.Л. Аналитический доклад «Проблемы и перспективы развития отечественной авиационной промышленности», Межведомственный аналитический центр, февраль 2011 г.

6. Колпаков С.К. История авиационной промышленности России. Режим доступа. URL:http://www.ru-90.ru/node/1322

7. Российская авиационная отрасль: переломный момент.Режим доступа.URL:http://www.strategy.ru/UserFiles/File/Doklad/2013_Russian\%20 aviation.pdf

8. Информационно-исторический официальный интернет-сайт «Министерство авиационной промышленности СССР». Режим доступа. URL:http://www.mapsssr.ru 